\title{
Genetic variation and phylogenetic analysis of Indonesian indigenous catfish (baung fish) based on mitochondrial 12S rRNA gene
}

\author{
Rini Widayanti ${ }^{(D)}$, Ken Ayik Kusumaastuti ${ }^{1}$, Joana Martha Novi1(iD, Fadila Khairuna Adani1 (D), \\ Catrine Relia Patrecia Gultom ${ }^{1} \mathbb{D}$, Ayuning Devina Prastiti ${ }^{1}$, , Herjuno Ari Nugroho ${ }^{(\mathbb{D}}$ and Suhendra Pakpahan ${ }^{2}$ (D) \\ 1. Department of Biochemistry and Molecular Biology, Faculty of Veterinary Medicine, Universitas Gadjah Mada, \\ Yogyakarta, Indonesia; 2. Research Center for Biology, Indonesian Institute of Sciences (LIPI), Jl. Jakarta-Bogor KM 46, \\ Cibinong, West Java, Indonesia. \\ Corresponding author: Suhendra Pakpahan, e-mail: suhendrapakpahan@gmail.com \\ Co-authors: RW: rini_widayanti@ugm.ac.id, KAK: ken.ayik.kusumaastuti@mail.ugm.ac.id, \\ JMN: joana.martha.novi@mail.ugm.ac.id, FKA: fadila.k@mail.ugm.ac.id, CRPG: catrine.r@mail.ugm.ac.id, \\ ADP: ayuning.devina.prastiti@mail.ugm.ac.id, HAN: herjunoari@gmail.com \\ Received: 20-11-2020, Accepted: 05-02-2021, Published online: 24-03-2021
}

doi: www.doi.org/10.14202/vetworld.2021.751-757 How to cite this article: Widayanti R, Kusumaastuti KA, Novi JM, Adani FK, Gultom CRP, Prastiti AD, Nugroho HA, Pakpahan S (2021) Genetic variation and phylogenetic analysis of Indonesian indigenous catfish (baung fish) based on mitochondrial 12S rRNA gene, Veterinary World, 14(3): 751-757.

\begin{abstract}
Background and Aim: Baung fish is an essential commodity in Indonesia; however, few studies have explored the genetic diversity of Indonesian catfish. Thus, this study aimed to analyze the genetic variation and phylogenetic relationships among Indonesian catfish based on the mitochondrial $12 S$ ribosomal $R N A(r R N A)$ gene.
\end{abstract}

Materials and Methods: In total, 28 catfish were collected from nine rivers in seven provinces and from the Indian Ocean. Catfish genomes were obtained from epaxial and hepaxial muscle samples. The mitochondrial $12 S$ rRNA gene was amplified by polymerase chain reaction using a pair of primers (Baung12SF and Baung12SR). The $12 S r R N A$ sequences were analyzed using MEGA X to determine genetic variation and phylogenetic relationships.

Results: In total, 178 variation sites in the $12 S$ rRNA gene were substituted among Indonesian catfish. The genetic distance between all Indonesian catfish samples was $0.1-16.0 \%$. The closest genetic distance was between MP and PM catfish, whereas the farthest genetic distances were between BF and EM and PD and EM. For the entire population, based on mean diversity calculations, the number of base substitutions per site was 0.08 .

Conclusion: Indonesian catfish were divided into four clades based on the $12 S r R N A$ gene. The catfish MP, KR, PM, MS, $\mathrm{BB}$, and KS were grouped with Hemibagrus nemurus, the catfish EM was grouped with Mystus vittatus, the catfish BSBJ was grouped with Pangasius pangasius, and the catfish PD and BF were grouped with Netuma thalassina.

Keywords: $12 S$ ribosomal RNA gene, baung fish, Hemibagrus nemurus, Indonesian catfish, phylogenetic.

\section{Introduction}

Indonesia is a country with enormous biodiversity (i.e., "mega biodiversity"). For example, around $16 \%$ of the world's fish species are found in Indonesia, and 2000 of these 7000 fish species are freshwater fish. Thus, the freshwater fish population of Indonesia is second only to that of Brazil [1]. Baung fish (Hemibagrus nemurus) is an essential commodity in Indonesia because it is widely consumed and contains essential nutrients. For example, baung fish are a valuable source of protein, lipids (with large amounts of omega-3, omega-6, monounsaturated fatty acids, docosahexaenoic acid, and eicosapentaenoic acid), minerals, albumin, and antioxidants [2-4].

The distribution of baung fish is relatively wide in the islands of Java, Sumatra, and Kalimantan [5].

Copyright: Widayanti, et al. Open Access. This article is distributed under the terms of the Creative Commons Attribution 4.0 International License (http://creativecommons.org/licenses/ by/4.0/), which permits unrestricted use, distribution, and reproduction in any medium, provided you give appropriate credit to the original author(s) and the source, provide a link to the Creative Commons license, and indicate if changes were made. The Creative Commons Public Domain Dedication waiver (http:// creativecommons.org/publicdomain/zero/1.0/) applies to the data made available in this article, unless otherwise stated.
In different regions of Indonesia, this fish are known by other names such as Duri, Baon (Malay), Bawon (Betawi), Senggal or Singgah (Sunda), Tagih or Tageh (Java), and Tiken bato (Central Kalimantan). Iqbal [6] reported that 60 species of baung fish exist in Indonesia, three of which are found in the Hutan Rawa Gambut Merang Kepayang Banyuasin, South Sumatra. These types are a beringit fish (Mystus singaringan) two types of baung fish (Hemibagrus hoevenii and Bagroides macropterus).

The genetic markers of baung fish have been studied to identify species and preserve genetic resources; however, given the size of the aquaculture industry in Indonesia, relatively few studies have been conducted [7]. The diversity of the nucleotides of each species can be used as genetic markers, which can be used to construct phylogenetic trees and complement current molecular data that are currently lacking [8,9]. Mitochondria are membrane-bound cell organelles that generate most of the chemical energy needed to power biochemical reactions in the cell. Mitochondrial DNA contains 37 genes, all of which are essential for normal mitochondrial function. Transfer RNA (tRNA) and ribosomal RNA (rRNA) are types of RNA that 
help assemble amino acids into functioning proteins. The $12 S$ and $16 S$ rRNA mitochondrial genes are relatively conserved; they have evolved more slowly than the mitochondrial genome as a whole and can be used as genetic markers for the identification of species and in forensic investigations [10-12].

To date, few studies have explored the genetic diversity of Indonesian catfish. Thus, the present study aimed to characterize Indonesian catfish from different provinces (those known as baung fish by local people) and to determine the diversity among them using $12 S$ rRNA gene sequences and comparisons with the available GenBank sequence. Moreover, the genetic variability of the $12 S \mathrm{rRNA}$ gene in catfish was measured to determine the variation and relationships among Indonesian catfish from different regions.

\section{Materials and Methods}

\section{Ethical approval}

This study was approved by the Animal Ethics Committee for using Animal and Scientific Procedures in Faculty of Veterinary Medicine, Universitas Gadjah Mada, Indonesia.

\section{Study period and location}

The collection of catfish samples was carried out from 2017-2020, but for the study of Genetic variation and phylogenetic analysis of Indonesian indigenous catfish (baung fish) based on mitochondrial $12 \mathrm{~S} r R N A$ gene, it was conducted from January to September 2020 in the Laboratory of Biochemistry and Molecular Biology, Faculty of Veterinary Medicine, Gadjah Mada University.

\section{Catfish collections}

Baung fish DNA was obtained from 28 samples of the epaxial and hepaxial muscles of fish from various rivers in Indonesia and from the Indian Ocean. Table-1 shows the origin, number, and code of the baung fish. All individuals were identified based on morphological characteristics and sample tissues were preserved in RNAlater buffer (Qiagen). The catfish samples in this study were considered to be unrelated

Table-1: Origin and number of Indonesian catfish.

\begin{tabular}{|c|c|c|c|}
\hline River/Sea & Province & Number & Sample CODE \\
\hline Progo river & Central Java & 3 & PM1, PM2, PM3 \\
\hline Elo river & Central Java & 2 & EM1, EM2 \\
\hline $\begin{array}{l}\text { Bengawan Solo } \\
\text { river }\end{array}$ & Central Java & 3 & $\begin{array}{l}\text { BSBJ1, BSBJ2, } \\
\text { BSBJ3 }\end{array}$ \\
\hline Kampar river & Riau & 3 & $\mathrm{KR} 1, \mathrm{KR} 2, \mathrm{KR} 3$ \\
\hline Musi river & $\begin{array}{l}\text { South } \\
\text { Sumatra }\end{array}$ & 3 & MP1, MP2, MP3 \\
\hline Mahakam river & $\begin{array}{l}\text { East } \\
\text { Kalimantan }\end{array}$ & 3 & MS1, MS2, MS3 \\
\hline Kapuas river & $\begin{array}{l}\text { West } \\
\text { Kalimantan }\end{array}$ & 2 & $\mathrm{KS} 1, \mathrm{KS} 2$ \\
\hline Martapura river & $\begin{array}{l}\text { South } \\
\text { Kalimantan }\end{array}$ & 3 & $\mathrm{BB} 1, \mathrm{BB} 2, \mathrm{BB} 3$ \\
\hline Bomberay river & West Papua & 4 & $\begin{array}{l}\mathrm{BF} 1, \mathrm{BF} 2, \mathrm{BF} 3, \\
\mathrm{BF} 4\end{array}$ \\
\hline Indian Ocean & Yogyakarta & 2 & PD 1, PD2 \\
\hline
\end{tabular}

genetically because they were taken individually from the rivers and ocean. Catfish were collected from the ocean to determine the relationship and genetic diversity between river catfish and sea catfish.

\section{DNA extraction and 125 rRNA gene amplification}

The total DNA of catfish was extracted using a gSYNCTM DNA Mini Extraction Kit (Geneaid Biotech Ltd., Taiwan) following the manufacturer's instructions and then stored at $-20^{\circ} \mathrm{C}$ until use. The $12 S r R N A$ fragments of the target region were amplified by polymerase chain reaction (PCR) using a pair of primers: Baung12SF: 5'-TAA CAC TGA AGA TGT TAA GA-3' and Baung12SR: 5'-TAG CTA AAT CAT GAT GCA AA-3'. The PCR reaction was conducted in a total volume of $50 \mu \mathrm{L}$, comprising $25 \mu \mathrm{L}$ of master mix (Kapa2G ReadyMix, $1^{\text {st }}$ Base), $2 \mu \mathrm{L}$ of DNA template, $1 \mu \mathrm{L}$ (10 pmol) of each primer, and 21 $\mu \mathrm{L}$ of distilled water. Reaction cycles in an Infinigen Thermocycler comprised an initial denaturing step at $94^{\circ} \mathrm{C}$ for $5 \mathrm{~min}$, followed by 35 cycles at $94^{\circ} \mathrm{C}$ for $30 \mathrm{~s}, 41^{\circ} \mathrm{C}$ for $45 \mathrm{~s}$, and $72^{\circ} \mathrm{C}$ for $90 \mathrm{~s}$, with a final extension at $72^{\circ} \mathrm{C}$ for $5 \mathrm{~min}$. DNA amplifications were confirmed by $1 \%$ agarose gel electrophoresis with a 100 bp DNA ladder (Genaid) used for genotyping.

\section{Sequences and phylogenetic analysis}

All purified PCR products were sequenced directly by $1^{\text {st }}$ Base Sequencing INT using forward and reverse primers. The fragments of forward and reverse $12 S r R N A$ gene sequences were aligned using ClustalW and edited, and then, multiple alignments were performed with data linked to $H$. nemurus and other catfish from the NCBI database. Fragments of the $12 S$ rRNA gene were analyzed for 956 nucleotides. Genetic distance was determined using the Kimura two-parameter method and phylogenetic relationships were assessed through the neighbor-joining (NJ) method using MEGA X version 10.1 (https:// www.megasoftware.net) [13]. The bootstrap method for genetic distance analysis included 1000 replicates. A phylogenetic tree was constructed based on $12 S$ rRNA sequences, and catfish sequences from other countries were used to reveal relationships and clusters among catfish. To construct the phylogenetic tree and determine relationships among catfish, the sequences of comparison species were obtained from the NCBI database: H. nemurus (KJ573466.1), Mystus cavasius (KU870465.1), Pangasius pangasius (KC572135.1), Pangasianodon gigas (AY762971.1), Arius arius (KX211965.1), and Netuma thalassina (MG587041.1).

\section{Results \\ Genetic variation of Indonesian catfish based on the $12 S$ rRNA gene}

The $12 S$ rRNA gene had a length of $959 \mathrm{bp}$ and was located between the $t R N A$-Phe gene and the $t R N A$ Val gene. The amplified DNA fragments were $1309 \mathrm{bp}$ in length and comprised $t R N A$-Phe (46 bp), $12 S r R N A$ (956 bp), tRNA-Val (72 bp), and 16S rRNA (235 bp). 
The average respective percentage of nucleotide $T$, $\mathrm{C}, \mathrm{A}$, and $\mathrm{G}$ from each group sample was as follows: PM $(22.8 \%, 24.9 \%, 31.6 \%$, and $20.7 \%)$; EM (22.9\%, $23.6 \%, 32.9 \%$, and $20.6 \%)$; BSBJ $(21.9 \%, 25.6 \%$, $31.7 \%$, and $20.9 \%)$; BF $(20.2 \%, 27.8 \%, 30.6 \%$, and $21.4 \%)$; KR $(22.9 \%, 24.8 \%, 31.6 \%$, and $20.7 \%)$; MP $(22.8 \%, 24.9 \%, 31.7 \%$, and $20.6 \%)$; MS $(23.1 \%$, $24.6 \%, 31.8 \%$, and $20.6 \%)$; KS $(22.9 \%, 24.8 \%$, $31.6 \%$, and $20.7 \%)$; BB $(23.0 \%, 24.7 \%, 31.4 \%$, and $20.9 \%)$; and PD $(20.0 \%, 27.9 \%, 31.2 \%$, and $20.9 \%)$.

Among all samples, 178 variation sites existed in the $12 S$ rRNA gene, which were nucleotides substituted among the Indonesian catfish, but deletions and insertions were not found. The alignment was conducted with ClustalW based on comparisons with the PM1 sample sequence. The homology of each sample against the PM1 sample is indicated by a dot in Figures-1-3. Alignment of all sequences indicated that genetic variation existed among Indonesian catfish samples. The catfish EM, BSBJ, BF, and PD had high variation relative to the catfish PM. Several unique variation sites were identified that could serve as genetic markers for populations: EM sites 59, 372, $464,477,577,586,606$, and 651 ; BSBJ sites 27, 118, $119,216,219,406,476,484,494$, and 608; BF sites $116119,320,730,780$, and 907 ; MS site 339; and MP sites $1,68,71,116,127,141,201,390,454,472,474$, 730, 750, and 764 (Figures-1-3).

\section{Genetic distance analysis based on 125 rRNA gene sequences}

Baung fish from Kalimantan (MS, KS, and BB), Sumatra (MP and KR), and Java (PM) were identified as Hemibagrus spp. with a genetic distance of 0.1$6.0 \%$ (Table-2). Catfish EM and BSBJ were identified as Mystus spp. and Pangasius spp., respectively.
Fifteen sites were found in the nucleotide variation of the $12 S r R N A$ gene that could be used as genetic markers among Indonesian catfish. Genetic markers distinguished baung fish from the Bomberay River, West Papua (BF1, BF2, BF3, and BF4), which were identified as Netuma spp. with a genetic distance of $5.2 \%$. Fifty sites were found in the nucleotide variation that could be used as genetic markers for fish samples from the Bomberay River. The genetic distance between all samples of Indonesian catfish was $0.1-16.0 \%$.

After averaging across all sequence pairs between groups, the number of base substitutions per site was calculated for the entire population as 0.08 (Table-2). Genetic distances were obtained by bootstrapping (1000 replicates) and analyses were conducted using the Kimura two-parameter model [14]. All ambiguous positions were removed for each sequence pair (i.e., the pairwise deletion option). Although the genetic distances between the Indonesian catfish samples in this study were from 0.001 to 0.161 , the closest genetic distance was between catfish MP to PM, whereas the farthest genetic distances were between catfish BF and EM and PD to EM.

\section{Phylogenetic relationships of Indonesian catfish}

A phylogenetic tree of Indonesian catfish and other catfish from the NCBI database was constructed using the NJ method [15]. The optimal phylogenetic tree (sum of branch lengths $=0.38391001$ ) is shown in Figure-4. The percentage of replicate trees in which the associated taxa clustered together in the bootstrap test is shown next to the branches [16]. The tree is drawn to scale, with its branch lengths in the same units as those of the evolutionary distances used to infer it. The evolutionary distances are shown as the number of base

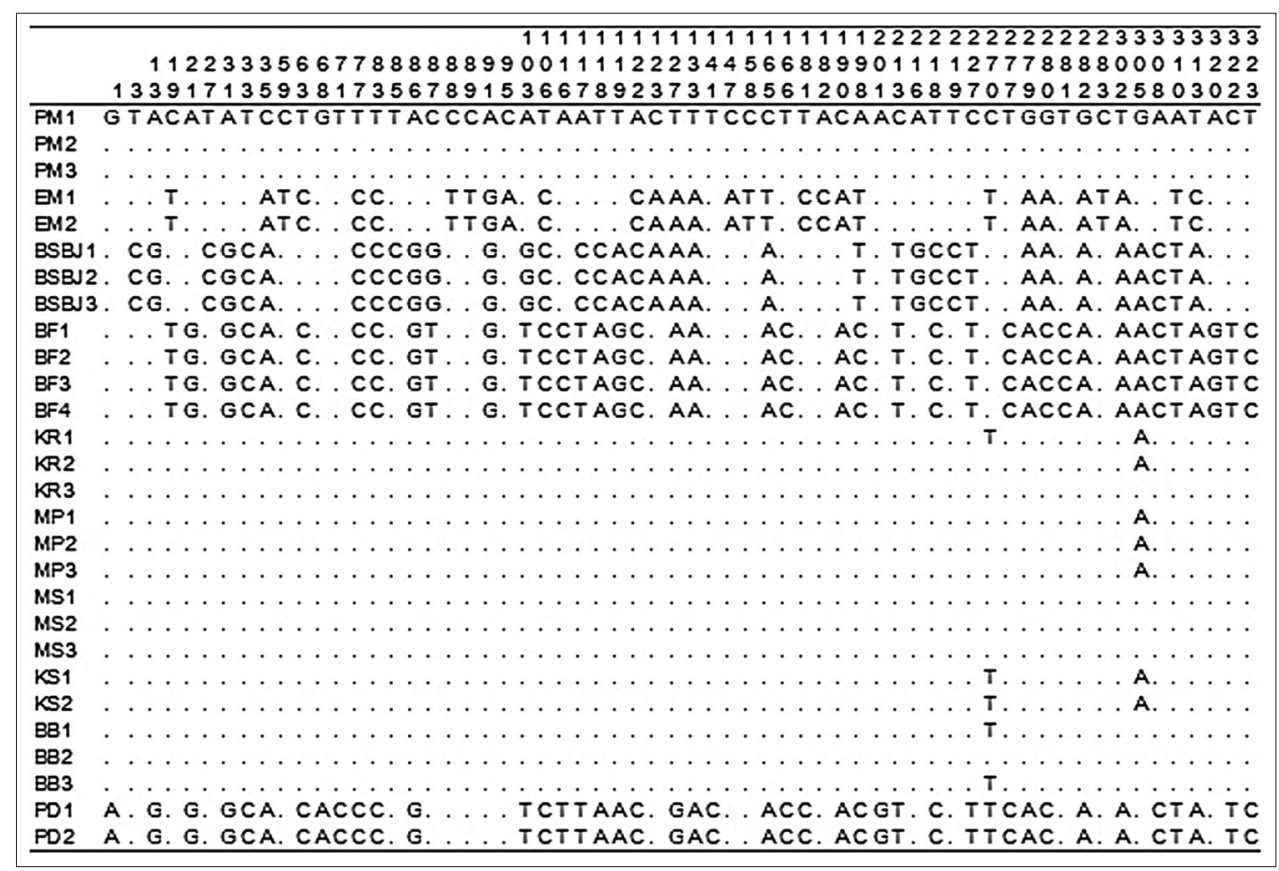

Figure-1: Polymorphic sites in 12S rRNA gene of Indonesian catfish from site 1 to 323. Identity with the first sequences is denoted by a dot. 


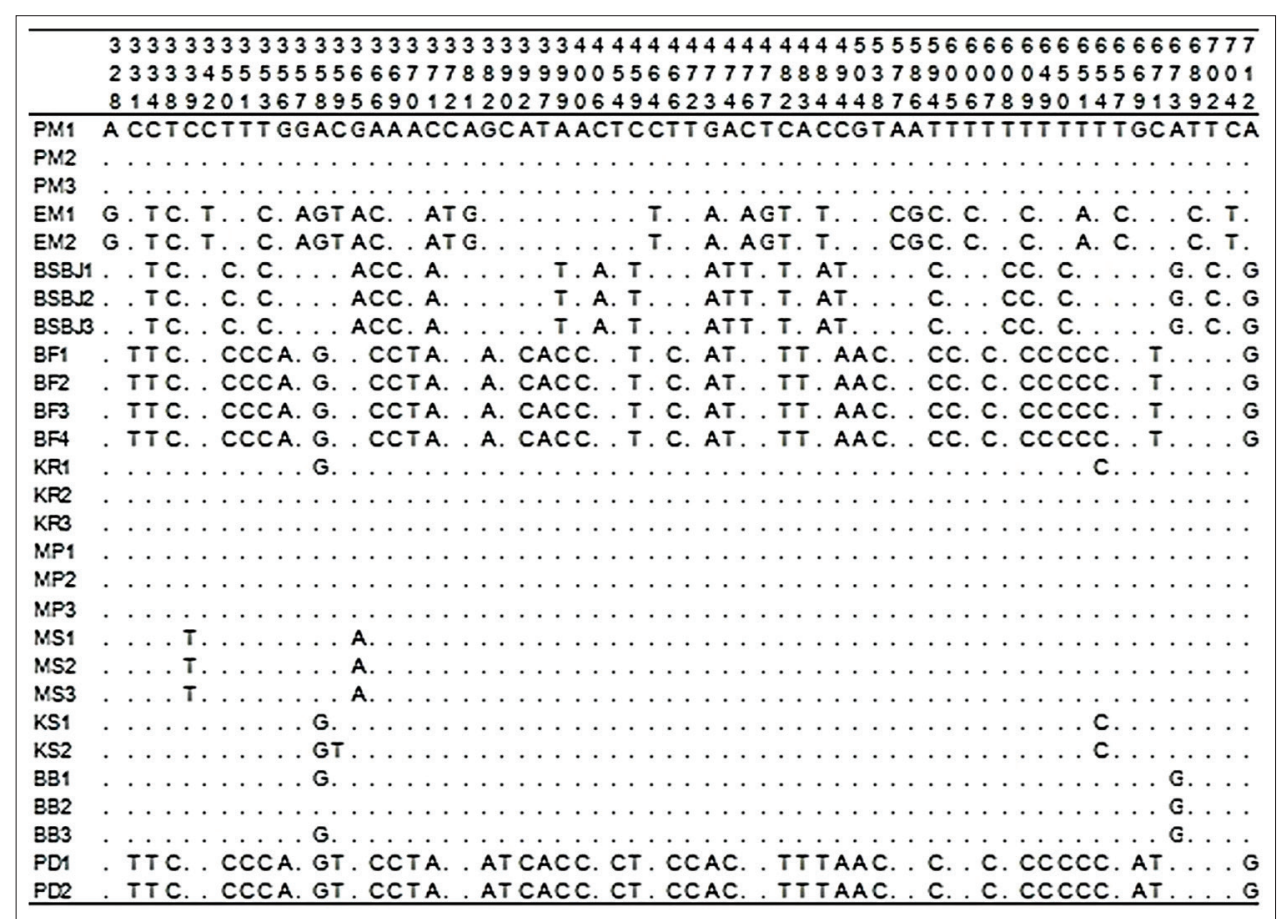

Figure-2: Polymorphic sites in $12 S$ rRNA gene of Indonesian catfish from site 328 to 712 . Identity with the first sequences is denoted by a dot.

\begin{tabular}{|c|c|}
\hline & $\begin{array}{l}77777777777777777777777778888888888888888888888899999999999 \\
33344444555566667777777780011111367777778888999900000000111\end{array}$ \\
\hline & 0 \\
\hline PM1 & T TATATACTACACACTTCGGTGTAGGTCACCTATTTTCCTTTTATCAAACCACC \\
\hline 12 & $\ldots \ldots \ldots \ldots \ldots \ldots \ldots \ldots \ldots \ldots \ldots \ldots \ldots \ldots \ldots \ldots \ldots$ \\
\hline 13 & - \\
\hline EM1 & $\ldots$ AT. . T. T. TGA. . TT. CA. T. . CTC. . A. A. T. CAAC. AT . T T. TT . . \\
\hline EM2 & . . AT. . T. . T. TGA. . TT. CA. T. . CTC. . A. A. T. CAAC. AT. . TT. TT. . . \\
\hline ;BJ1 & A. C. T. TG. . C. AAA. CT . AC. T. . A. TA. ACC. . CT. ATT . TT. TT \\
\hline 汭 2 & A. C. T. . TG. . C. AAA. . CT . AC. T. . A. TA. ACC. . CT. ATT . TT.TT \\
\hline$\sqrt{3}$ & . A. C. T. TG. . C. AAA. C . . AC. T. . A. TA. ACC. . CT. ATT . TT. TT \\
\hline BF1 & GCGA. CG. . G. G. . TCC. A. . CCA. . ACTTCG. CCC. A. ACCT. . C. CA. . AAT. TGCT \\
\hline 2 & GCGA. CG. . G. G. . TCC. A. . CCA. . ACTTCG. CCC. A. ACCT. . C. CA. . AAT. TGCT \\
\hline$B F 3$ & GCGA. CG. . G. G. . TCC. A. . CCA. . ACTTCG. CCC. A. ACCT. . C. \\
\hline BF4 & GCGA. CG. . G. G. . TCC. A. . CCA. . ACTTCG. CCC. A. ACCT. . C. CA. . AAT. TGCT \\
\hline KR1 & . . . . . . . . . . . \\
\hline KR2 & $\ldots \ldots \ldots \ldots \ldots \ldots$ \\
\hline 23 & 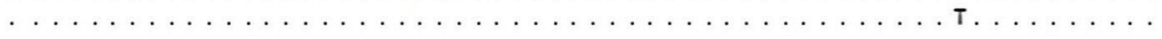 \\
\hline MP1 & . \\
\hline MP2 & 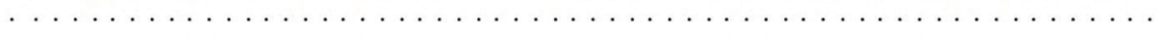 \\
\hline 3 & 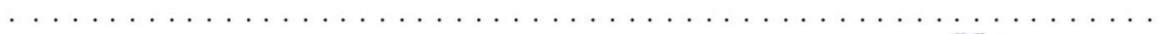 \\
\hline MS1 & 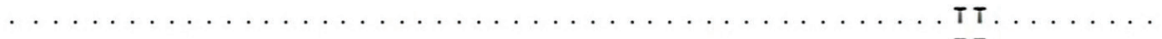 \\
\hline MS2 & 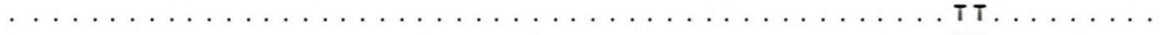 \\
\hline MS3 & $\ldots \ldots \ldots \ldots \ldots \ldots \ldots \ldots \ldots$ \\
\hline KS1 & 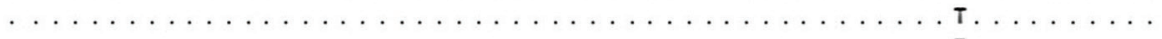 \\
\hline KS2 & 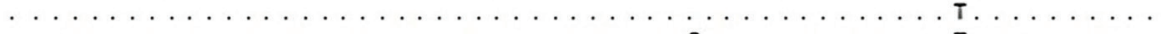 \\
\hline B81 & 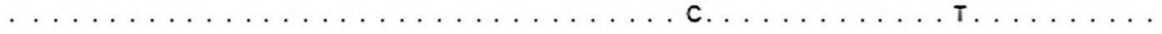 \\
\hline 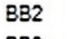 & $\ldots \ldots \ldots \ldots \ldots \ldots \ldots \ldots \ldots \ldots \ldots \ldots \ldots \ldots$ \\
\hline BB3 & 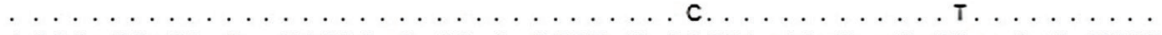 \\
\hline PD1 & CGA. CG. CG. G. . TACTA. C. CC. A. ACT T. G. CCCTA. AC. T. . C. CA. . A. C. TGCT \\
\hline PD2 & CGA. CG. CG. G. . TACTA. C. CC. A. ACTT. G. CCCTA. AC.T. C. CA. . A. C. TGCT \\
\hline
\end{tabular}

Figure-3: Polymorphic sites in 125 rRNA gene of Indonesian catfish from site 730 to 915 . Identity with the first sequences is denoted by a dot.

substitutions per site. In total, 34 nucleotide sequences were analyzed. After all ambiguous positions were removed for each sequence pair, 970 positions existed in the final dataset. Evolutionary analyses were conducted in MEGA X [13].

The $12 S$ rRNA nucleotide sequence was used to examine the phylogenetic relationship among all
Indonesian catfish samples and some catfish from other countries (Figure-4). First, alignment was performed in ClustalW, and then forward and reverse sequences were edited in MEGA X. A phylogenetic tree containing 28 Indonesian catfish was constructed. In this tree, the Indonesian catfish were divided into four clades with the catfish from other countries. The 
Table-2: Estimates of evolutionary divergence over sequence pairs between groups.

\begin{tabular}{|c|c|c|c|c|c|c|c|c|c|c|}
\hline & PM & EM & BSBJ & BF & $\mathbf{K R}$ & MP & MS & KS & BB & PD \\
\hline \multicolumn{11}{|l|}{ PM } \\
\hline EM & \multicolumn{10}{|l|}{0102} \\
\hline \multicolumn{11}{|c|}{ BSBJ 01060116} \\
\hline BF & \multicolumn{10}{|c|}{014101610103} \\
\hline $\mathbf{K R}$ & \multicolumn{10}{|c|}{0002010201060139} \\
\hline MP & \multicolumn{10}{|c|}{00010103010501390002} \\
\hline MS & \multicolumn{10}{|c|}{000401000104014600050005} \\
\hline KS & \multicolumn{10}{|c|}{0006010001090139000300050008} \\
\hline BB & \multicolumn{10}{|c|}{0005010101070141000500060007000} \\
\hline PD & \multicolumn{10}{|c|}{015101610116004701510153015701480150} \\
\hline
\end{tabular}

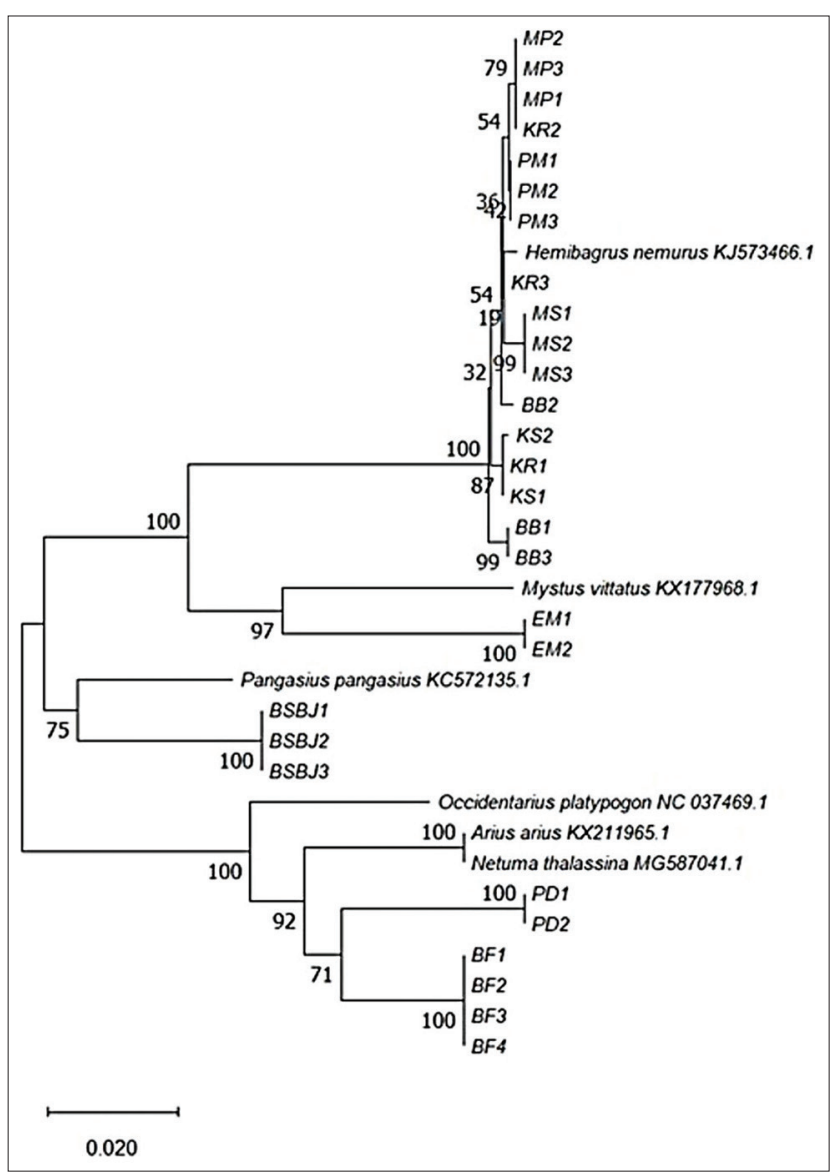

Figure-4: Phylogenetic relationship of Indonesian catfish based on $12 S$ rRNA gene sequences.

catfish MP, KR, PM, MS, BB, and KS were grouped with $H$. nemurus, the catfish EM was grouped with Mystus vittatus, the catfish BSBJ was grouped with P. pangasius, and the catfish $\mathrm{PD}$ and $\mathrm{BF}$ were grouped with $N$. thalassina. These four groups were supported by bootstrapping at approximately $75-100 \%$ NJ.

\section{Discussion}

\section{Determining the species of Indonesian catfish based on the 125 rRNA gene}

Throughout their distribution area in Indonesia, Hemibagrus spp. are the fish most widely consumed as food. Thus, species identification is important for the sustainable use of this species complex [17]. Much of the biodiversity in the Indonesian archipelago has yet to be identified and/or characterized including catfish.
Indeed, local Indonesian people typically use the same name for all types of catfish. Morphologically determination of species of catfish is difficult because they are highly similar in this respect. Thus, the genetic analysis provides more accurate information regarding the diversification and evolutionary relationships among species $[18,19]$. Such analysis is vital as catfish are found throughout the fresh and brackish waters of Asia and Africa, with more than 200 species known to exist in 17 genera, making catfish one of the largest fish families [20].

Mitochondrial DNA is popular as a target for species identification and the study of genetic diversity because it includes more mitochondrial DNA than nuclear DNA, has high variation, and lacks recombination [21]. Based on previous research by Megarani et al. [22], Indonesian catfish can be divided into five clades based on the Cyt $B$ gene: The H. nemurus and Hemibagrus wyckioides (family Bagridae) group; the Sperata seenghala and Hemibagrus spilopterus (family Bagridae) group; the Pseudolais pleurotaenia (family Pangasiidae) group; the M. cavasius (family Bagridae) group; and the Potamosilurus latirostris (family Ariidae). Syaifudin et al. [23] identified freshwater fish in South Sumatra, such as baung (H. nemurus), beringit (M. singaringan), gabus (Channa striata), serandang (Channa pleurophthalma), and sepat (Trichogaster spp.), using the Cytochrome C oxidase subunit I (COI) $m t D N A$ sequence; the COI mtDNA gene can be used to differentiate fish at the species level and shows effective and accurate species relatedness. Thus, both the $12 S$ rRNA and COI mtDNA genes are recommended for the identification and analysis of genetic diversity between species $[11,24]$.

The present study used a similar sample to that researched by Megarani et al. [22], but one group differed, namely, the PD sample. The type of mitochondrial gene studied also differed between the two studies. Here, all sequences of the $12 S r R N A$ gene were blasted in the NCBI database; the results indicated that Indonesian catfish comprise four groups: $H$. nemurus, $M$. vittatus, $P$. pangasius, and $N$. thalassina/A. arius.

\section{Phylogenetics and phylogeographics of Indonesian catfish}

Based on research by Dodson et al. [25], the biogeographical history of Southeast Asia contributed to extensive admixture during the Pleistocene low sea-levels of genetic groups of an obligate the river catfish that isolated during periods of high sea levels. In this study, one type of catfish was taken directly from the Indian Ocean, that is, catfish PD. The $12 \mathrm{~S}$ $r R N A$ sequence analysis showed that this catfish had a close genetic relationship with catfish BF that originated from Papua Island, and these two catfish had a close genetic relationship with $N$. thalassina.

H. nemurus, allegedly from Southeast Asia, has previously been reported to have broad genetic subdivisions based on molecular phylogenetic analysis and phylogeography $[17,23,25]$. The results of the present 
study support those of previous studies, that is, that many species of Bagridae exist in Indonesia (about 60 species). Four species were identified here from various Indonesian islands, namely, the species $H$. nemurus, $M$. vittatus, $P$. pangasius, and $N$. thalassina (or A. arius). Most samples were of $H$. nemurus, which originated from the islands of Sumatra, Java, and Kalimantan (namely, catfish MP, KR, PM, MS, KS, and BB). By contrast, catfish samples from Papua and the Indian Ocean belonged to $N$. thalassina or $A$. arius. The results of this grouping were supported by high bootstrap values of $75-100 \%$ NJ. Therefore, Indonesian catfish species and even subspecies can be identified and characterized based on phylogenetic analysis, which could help to successfully conserve species.

\section{Conclusion}

Indonesian catfish were divided into four clades based on analysis of the $12 S$ rRNA gene. The catfish $\mathrm{MP}, \mathrm{KR}, \mathrm{PM}, \mathrm{MS}, \mathrm{BB}$, and KS were grouped with $H$. nemurus, the catfish EM was grouped M. vittatus, the catfish BSBJ was grouped with P. pangasius, and the catfish PD and BF were grouped with $N$. thalassina and $A$. arius.

\section{Authors' Contributions}

RW and SP designed the research and collected Indonesian catfish samples for this study. SP, KAK, JMN, FKA, CRPG, ADP, and HAN conducted research in the laboratory. RW and SP analyzed the data and wrote the manuscript. All authors have read and approved the final manuscript.

\section{Acknowledgments}

The authors are thankful to Universitas Gadjah Mada, Indonesia for providing funding through the Research Directorate (Final Project Recognition, RTA: 732/UN1.P.III/KPT/HUKOR/2020) and Faculty of Veterinary Medicine, Universitas Gadjah Mada, Indonesia (the Research Development Department BPPTN-BHFKHUGMNo. 1011/J01.1.22/HK4/2019). The authors are also thankful to the laboratoryassistants of the Biochemical Laboratory for their support.

\section{Competing Interests}

The authors declare that they have no competing interests.

\section{Publisher's Note}

Veterinary World remains neutral with regard to jurisdictional claims in published institutional affiliation.

\section{References}

1. Akbar, J. (2014) Potensi dan Tantangan Budi Daya Ikan Rawa (Ikan Hitaman dan Ikan Putihan) di Kalimantan Selatan. Vol. 34. Unlam Press, Banjarmasin. p90-92.

2. Robert, T.R. (1989) The Freshwater Fishes of Western Borneo (Kalimantan Barat, Indonesia). Academy of Science, California. p210.

3. Mesomya, W., Cuptapun, Y., Jittanoonta, P., Hengsawadi, D.,
Boonsivut, S., Huttayanon, P. and Sriwatana, W. (2002) Nutritional evaluations of green catfish, Mystus nemurus. Kasetsart J. Nat. Sci., 36(1): 69-74.

4. Widayanti, R., Haryanto, A., Artama, W.T. and Pakpahan, S. (2019) Genetic variation and phylogenetic analysis of Indonesian indigenous catfish based on mitochondrial cytochrome oxidase subunit III gene. Vet. World, 12(6): 896-900.

5. Sukendi. (2001) Biologi Reproduksi dan Pengendaliannya dalam Upaya Pembenihan Ikan Baung (Hemibagrus nemurus) di Perairan Sungai Kampar, Riau, Disertasi S3 (Tidak dipublikasikan). Institut Pertanian Bogor, Bogor. p11.

6. Iqbal, M. (2011) Ikan-ikan di Hutan Rawa Gambut Merang Kepayang dan Sekitarnya. Merang REDD Pilot Project, Palembang. p35.

7. Gustiano, R., Kusmini, I. and Aththar, M.F.H. (2015) Mengenal Sumber Daya Genetik Ikan Spesifik Lokal Air Tawar Indonesia untuk Pengembangan Budidaya. IPB Press, Bogor. p51.

8. Widayanti, R., Suprayogi, T., Kunda, R.M. and Pakpahan, S. (2016) Phylogenetic relationship of cuscuses (Marsupialia: Phalangeridae) from Papua and Maluku based on mitochondrial sequences of NADH dehydrogenase sub-unit 1 gene. Biotechnology, 15(1/2): 17.

9. Pakpahan, S., Artama, W.T., Widayanti, R. and Suparta, I.G. (2016) Molecular phylogenetic of Hutan Sumatera goat (Sumatran serow) and domestic goat (Capra hircus) in Indonesia based on analysis mitochondrial cytochrome $\mathrm{b}$ gene. Asian J. Anim. Vet. Adv., 11(6): 331-340.

10. Yang, L., Tan, Z., Wang, D., Xue, L., Guan, M.X., Huang, T. and Li, R. (2014) Species identification through mitochondrial rRNA genetic analysis. Sci. Rep., 4(1): 4089.

11. Widayanti, R., Wijayanto, H., Wendo, W.D. and Kunda, R.M. (2015) Identification of genetic diversity of $12 S r R N A$ genes as a genetic marker for determining species cuscus.. J. Vet., 16(2): 227-235.

12. Satoh, T.P., Miya, M., Mabuchi, K. and Nishida, M. (2016) Structure and variation of the mitochondrial genome of fishes. BMC Gen., 17(1): 719.

13. Kumar, S., Stecher, G., Li, M., Knyaz, C. and Tamura, K. (2018) MEGA X: Molecular evolutionary genetics analysis across computing platforms. Mol. Biol. Evol., 35(6):1547-1549.

14. Kimura, M. (1980) A simple method for estimating evolutionary rate of base substitutions through comparative studies of nucleotide sequences. J. Mol. Evol., 16(2): 111-120.

15. Saitou, N. and Nei, M. (1987) The neighbor-joining method: A new method for reconstructing phylogenetic trees. Mol. Biol. Evol., 4(4): 406-425.

16. Felsenstein, J. (1985) Confidence limits on phylogenies: An approach using the bootstrap. Evolution, 39(4): 783-791.

17. Dodson, J.J., Colombani, F. and Ng, P.K.L. (1995) Phylogeographic structure in mitochondrial DNA of a South-East Asian freshwater fish, Hemibagrus nemurus (Siluroidei; Bagridae) and Pleistocene sea-level changes on the Sunda shelf. Mol. Ecol., 4(3): 331-346.

18. Buj, I., Šanda, R., Marčić, Z., Ćaleta, M. and Mrakovčić, M. (2014) Combining morphology and genetics in resolving taxonomy a systematic revision of spined loaches (Genus Cobitis; Cypriniformes, Actinopterygii) in the Adriatic watershed. PLoS One, 9(6): e99833.

19. Ikabanga, D.U., Stevart, T., Koffi, K.G., Monthe, F.K., Doubindou, E.C.N., Dauby, G. and Hardy, O.J. (2017) Combining morphology and population genetic analysis uncover species delimitation in the widespread African tree genus Santiria (Burseraceae). Phytotaxa, 321(2): 166-180.

20. Ferraris, C.J. (2007) Checklist of catfishes, recent and fossil (Osteichthyes: Siluriformes), and catalog of Siluriformes primary types. Zootaxa, 1418(1): 1-628.

21. Parson, W., Pegoraro, K., Niederstatter, H., Foger, M. and Steinlechner, M. (2000) Species identification by means of the cytochrome B gene. Int. J. Legal Med., 114(1-2): 23-28. 
22. Megarani, D.V., Nugroho, H.A., Andarini, Z.P., Surbakti, Y.D.R. and Widayanti, R. (2020) Genetic characterization and phylogenetic study of Indonesian indigenous catfish based on mitochondrial cytochrome B gene. Vet. World, 13(1): 96.

23. Syaifudin, M., Jubaedah, D., Muslim, M. and Daryani, A. (2018) DNA authentication of Asian redtail catfish Hemibagrus nemurus from Musi and Penukal river, South Sumatra Indonesia. Genet. Aquat. Organ., 1(1): 43-48.
24. Mochamad, S., Wijayanti, M., Dwinanti, S.H., Mahendra, M. and Marliana, S. (2020) DNA barcodes and phylogenetic of striped snakehead and ocellated snakehead fish from South Sumatra, Indonesia. Biodivers. J. Biol. Divers., 21(3): 210350.

25. Dodson, J.J. and Lecomte, F. (2015) A DNA barcode-based evaluation of the Southeast Asian catfish genus Hemibagrus Bleeker, 1862 (Teleostei: Siluriformes; Bagridae). Adv. Evol. Biol., 2015(1): 21.

$* * * * * * * *$ 